\title{
THE CAMPAIGNING SOLDIER: VITELLIUS' ENTRY INTO ROME
}

Tacitus' account of Vitellius' triumphal entry into Rome is used by the author to underline his disapproval of this emperor. However the historian's description of the Vitellian army has often been seen as positive and in sharp contrast to that given to the emperor himself. This article attempts to show that on close inspection Tacitus' account is equally hostile to the emperor's troops and that his disapproval is reinforced by his dwelling upon the colour

of their uniforms and the varied associations this would have had in the Roman mind.

Although we have no biography of Tacitus we can be sure that the first decad of Livy would have supplied him with much heartening reading. It is here that we find the stories of the military heroism of the Early Republic which embody ideals close to the historian's heart. Throughout Tacitus' work it is striking how often he uses the theme of the «noble soldier» to act as a foil to the gloomy picture which he paints of decadence and stagnation at Rome.

It is this that makes Tacitus' depiction of Vitellius' entrance into Rome at the end of the second book of the Histories particularly interesting, for Vitellius and his army are portrayed as anti-types of what Tacitus most admired. However there is one apparent sharp inconsistency within Tacitus' narration of these events which repays further study.

Vitellius entered Rome after defeating Otho's army at Cremona. Tacitus breaks his narrative to give an account of his rival, Vespasian, being acclaimed as emperor in the East. Although this could be justified chronologically, with the advantage of hindsight we are immediately prejudiced against Vitellius by Tacitus' arrangement of his material. While a prudent commander would have taken precautions against a gathering threat, all Vitellius does is posture and wallow in debauchery for, as Tacitus has already made clear, this general is no strategist or martinet ${ }^{1}$. Certainly neither the account of the commander nor

' See the complaints of Vitellius' own army about his slovenly strategy earlier in the rebellion, Tacitus, Hist. II 62. Tacitus underlines this vice in Histories II 73. 
that of his troops as they approach the city is flattering. Vitellius is sunk in depravity associating with characters from the demi-monde or worse. His men are said to have presented a saeuim spectaculum and to have «bristled» with huge spears, Tacitus here uses language more appropriate to barbarians than Roman legionaries. The troops' conduct lives up to this imagery; they are both seditious and divided among themselves, finding a unity of purpose only in attacking the Italian peasantry. Vitellius feeds them up like gladiators which is exactly how they behave ${ }^{2}$.

Vitellius, we are told, initially wanted to enter Rome in military dress and is said to have driven the senate and people before him as he approached the city ${ }^{3}$. The verb used here, agere, is redolent of a victorious commander driving his enemies from the field. However the victims are not the enemies of Rome but comprise the Roman state itself. Dissuaded from this path by his friends, Vitellius changes out of his military cloak, the paludamentum, into the civilian toga praetexta, and after forming up his men, with the implication that the advance up to this point had been disorderly, proceeds to enter the city at the head of his troops. Again there is a sharp contrast drawn by the historian. The toga praetexta was the badge of a civilian magistrate yet Vitellius enters Rome as a military commander at the head of an army. Vitellius' dress and the manner of his entrance are thus starkly at odds with one another, the latter pointing to the falsity of the impression that the former was intended to create. If Vitellius wished to present the image of being a ciuilis princeps, his manner of doing this, if we are to believe Tacitus, was singularly inept.

It appears that Tacitus wishes to underline the falsity of Vitellius' posturing. Perhaps we can detect artifice in his account from looking at our other sources. Suetonius tells us that Vitellius entered Rome in military dress ${ }^{4}$, coins struck by Vitellius show the emperor both in civilian and military garb ${ }^{5}$.

Tacitus' account continues relentlessly in similar vein. Vitellius' first act on entering the city is not to go to the curia which we would perhaps expect of a magistrate, but to the Capitolium - the destination of a triumphator. Not only does this again underline the hollowness of Vitellius' attempts not to appear as a conquering general, but the reader is also invited to ask himself

2 Tacitus, Histories II 56, II 88.

3 Tacitus, Histories II 89.

${ }^{4}$ Suetonius, Vitellius 11.

5 H. Mattingly, A Catalogue of Roman Coins in the British Museum (B.M.C.R.E.), vol. I, London 1923, p. 376. Type 49 of Vitellius' coinage shows Vitellius seated in front of three togate figures. Type 64 shows the emperor in military dress trying to raise a fallen female figure; a legend reads urbem re[stitutam?] - clearly Vitellius' minters wished to create a rather different impression of the emperor's entry into Rome to the one given to us by Tacitus. 
over whom has Vitellius triumphed. The answer can only be over his fellowcitizens or perhaps even the city of Rome itself.

Worse follows. On the Capitolium Vitellius greets his mother and honours her with the title Augusta, conjuring up in the readers' mind less than comforting reminiscences of Nero and Poppaea or Tiberius and Livia. Moreover we have already been told that his mother, a Roman matron of the old school ${ }^{6}$, cared nothing for such things, a fact which only serves to increase our deprecation of Vitellius' action. The following day he is said to have made a vainglorious and hypocritical speech extolling his own virtues as if he was in a foreign city ${ }^{7}$. Once again the sham of Vitellius the Roman magistrate has been replaced by Vitellius the conqueror of his own country.

Given the skill Tacitus spends on building up this picture of Vitellius, we would expect an equally dour description of the behaviour of his troops. However here Tacitus seems to confound our expectations. Vitellius' army is depicted in parade uniform marching through Rome, Tacitus concluding this passage with the phrase: «a glorious display and an army not worthy of an emperor like Vitellius» ${ }^{8}$.

Is Tacitus trying to contrast the valour and discipline of Vitellius' men to that of the new Emperor himself and to his disadvantage? This would be one reading of the text, and certainly most English translators have seen nothing but praise in Tacitus' description of the army here. However, given the context of the passage, perhaps caution would be in order. An army which has been involved in civil war and responsible for the desecration and destruction of the Italian countryside now dresses up in its best uniforms to march through Rome itself. This is hardly something a Roman could have looked upon with equanimity. Moreover the account of the pageant, couched in entirely Roman terms, clashes with markedly with Tacitus' descriptions of Vitellius' troops as virtually barbarians in the preceding chapter and with his account of the Vitellian army throughout the coup. Given that throughout this section of the Histories Tacitus seems to be playing with the idea that all is not what it seems, perhaps we ought to look for black humour in this account rather than uncritical praise.

The common soldiers are described as gleaming with their military awards. The reader is invited to ask himself in what circumstances these were won. If they were awarded during Vitellius' coup they could only be seen as a badge of shame by a Roman ${ }^{9}$, on the other hand if they had been won previous to

\footnotetext{
6 Tacitus, Histories II 64: antiqui moris.

7 tanquam apud alterius ciuitatis senatum.

8 Tacitus, Histories II 89: Decora facies et non Vitellio principe dignus exercitus.

Cf. the criticism of Caesar for celebrating a triumph after his Spanish campaign in $\mathbf{4 5}$
} BC. 
this they serve merely to contrast the troops' former glory with their present activities. However it is the dress of their commanders which merits most attention.

We are told that the praefecti castrorum, the tribuni, and primi centurionum were wearing shining white tunics, candidae uestes. This is a strange passage, which, although it is one of the few pieces of evidence for the colour of Roman military uniforms, has attracted remarkably little comment ${ }^{10}$.

However Tacitus' choice of word seems a little more barbed than a simple reference to Roman military parade dress. The fact that candidus is far more commonly used in poetry than prose should perhaps alert the reader to the fact that more than mere description is intended here. The word itself has a plethora of positive connotations, being frequently used to denote ritual purity, purity of mind, or as a sign of good fortune ${ }^{1 !}$.

None of these seem particularly appropriate for Vitellius' officers as they march through Rome. These are men who have led the fight against their fellow-citizens and their presence in the city, given their previous behaviour, can in the context of Tacitus' narrative only augur ill for the future.

Another meaning of the word also would not have been lost on Tacitus' original audience. Candidates for Roman elections normally presented themselves in a specially whitened toga, the toga candidata. Again the resonance is clear and certainly pejorative. In normal circumstances those dressed in gleaming white in Rome would be civilians participating in the electoral process. Here the word is used to emphasize the breakdown of normal political life in the city. The wearers of white are not candidates seeking election but rather conquerors imposing their settlement of affairs on Rome.

The advantage of such an interpretation of this passage is that it produces a much more harmonious reading given the general context. Instead of being forced to see Tacitus as praising a group he obviously detested, we can see how he uses his account of the military parade in Rome as part of a general strategy of bringing to light the hypocrisies of the Vitellian regime. Throughout his account of these events Tacitus endeavours to demonstrate to his readership that the reverse of the official position was the case. Vitellius' troops play a part in this strategy - they are not a foil to their leader, but rather a mordent mirror image of him.

\section{A. T. FEAR}

${ }^{10}$ For a brief discussion see N. Fuentes, "The Roman Military Tunic", in M. Dawson, ed., Roman Military Equipment: the accoutrements of war, Oxford 1987, p. 41 ss.

1 See the extensive entry in the Oxford Latin Dictionary, Oxford 1969, s.v. Candidus. 